\title{
Perlindungan Data Pribadi Penerima Pinjaman Dalam Transaksi Pinjam Meminjam Uang Berbasis Teknologi Informasi (Peer to Peer Lending)
}

\author{
Hendrawan Agusta \\ Pemerhati Hukum, Forseti Law Office \\ Korespondensi: hagusta@yahoo.com
}

Info Artikel

Diterima : 25 Jun 2020 Direvisi : 20 Jul $2020 \quad$ Disetujui : 4 Ags $2020 \quad$ Diterbitkan : 7 Des 2020

DOI: https://doi.org/10.31599/krtha.v14i2.189

Keywords : Information Technology, P2P Lending, Borrower and Personal Data Protection

Abstract : The development of information technology is very rapid, the collaboration between information technology and various fields of life bring in to various kinds of innovations that make people's lives easier. Innovations in information technology bring in to new business models which in turn can produce efficiency for the community. The information technology revolution continues to grow and now entering the financial sector which is highly regulated. Collaboration between information technology and finance bring in to Financial Technology (Fintech), which is information technologybased money-lending (Peer to Peer Lending/P2P Lending). It is easier for people to access their financial needs through P2P Lending. On the other hand, challenges arise in P2P Lending regarding data protection (personal data, transaction data and financial data). In this research, only the personal data of the Borrower will be discussed, where the personal data needs to be protected so there is no misuse that causes legal problems.

Kata kunci : Teknologi Informasi, Pinjam-Meminjam Uang Berbasis Teknologi Informasi, Penerima Pinjaman dan Perlindungan Data Pribadi

Abstrak : Perkembangan teknologi informasi sangat pesat, adanya kolaborasi antara teknologi informasi dengan berbagai bidang kehidupan melahirkan berbagai macam inovasi yang membuat kehidupan masyarakat semakin mudah. Inovasi di bidang teknologi informasi melahirkan model bisnis baru yang pada gilirannya mampu menghasilkan efisiensi bagi masyarakat. Revolusi teknologi informasi tersebut terus berkembang dan sekarang memasuki bidang keuangan yang regulasinya ketat. Kolaborasi antara teknologi informasi dengan bidang keuangan melahirkan Teknologi Finansial atau Financial Technology (Fintech), salah satunya pinjam-meminjam uang berbasis teknologi informasi (Peer to Peer Lending/P2P Lending). Masyarakat menjadi lebih mudah mengakses kebutuhan keuangannya melalui P2P Lending. Di sisi lain, muncul tantangan dalam P2P Lending mengenai perlindungan data (data pribadi, data transaksi dan data keuangan). Dalam penelitian ini yang akan dibahas hanya data pribadi Penerima Pinjaman, dimana data pribadi tersebut perlu dilindungi agar tidak terjadi penyalahgunaan yang menimbulkan permasalahan hukum. 


\section{PENDAHULUAN}

Teknologi informasi telah merubah pola hidup masyarakat secara global dan menyebabkan perubahan sosial budaya, ekonomi, dan kerangka hukum yang berlangsung dengan signifikan ${ }^{1}$. Hal ini mengakibatkan terciptanya suatu pasar baru yang telah mendorong perkembangan sistem ekonomi masyarakat, dari ekonomi tradisional yang berbasiskan industri manufaktur ke arah digital economy yang berbasiskan informasi, kreativitas intelektual dan ilmu pengetahuan yang juga dikenal dengan istilah creative economy ${ }^{2}$. James Adams dan Richard Kletter menyatakan bahwa technology has always disrupted the way we live and work, sometimes seemingly overnight ${ }^{3}$. Teknologi informasi dikatakan sebagai "pedang bermata dua" karena pada satu sisi menawarkan berbagai kemudahan, tapi pada sisi yang lain juga membawa beberapa permasalahan hukum yang krusial, antara lain masalah jaminan keaslian (keotentikan) data dan kerahasiaan dokumen (privasi) ${ }^{4}$. Apalagi saat ini muncul fenome Data is The New Oil, dimana data adalah jenis kekayaan baru yang lebih berharga daripada minyak (contohnya dalam kasus Cambridge Analytica) Perkembangan teknologi informasi telah melahirkan salah satu model bisnis baru di bidang keuangan, yaitu Financial Technology (Fintech). Kehadiran Fintech telah merubah pola hidup masyarakat di bidang keuangan karena muncul berbagai model bisnis baru yang memberikan kemudahan bagi masyarakat.

Teknologi Finansial (Fintech) adalah penggunaan teknologi dalam sistem keuangan yang menghasilkan produk, layanan, teknologi, dan/atau model bisnis baru serta dapat berdampak pada stabilitas moneter, stabilitas sistem keuangan, dan/atau efisiensi, kelancaran, keamanan, dan keandalan sistem pembayaran ${ }^{5}$. Selain definisi tersebut, terdapat beberapa definisi mengenai Fintech dari berbagai sumber ${ }^{6}$ :

\footnotetext{
${ }^{1}$ Rosalinda Elsina Latumahina, “Aspek Hukum Perlindungan Data Pribadi di Dunia Maya”, Jurnal Gema Aktualita, Vol. 3, No. 2, 2014, 14-25, hal. 14.

${ }^{2}$ Edmon Makarim, Tanggung Jawab Hukum Penyelenggara Sistem Elektronik, (Jakarta: Raja Grafindo Persada, 2010), hal 2.

${ }^{3}$ James Adams and Richard Kletter, Artificial Intelligence : Confronting The Revolution, (Middletown : Endeavour Media Ltd., 2018), hal. 19.

${ }^{4}$ Arsyad Sanusi, Konvergensi Hukum dan Teknologi Informasi,edisi revisi, (Jakarta : Sasrawarna Printing, 2011), hal. 5.

5Indonesia, Peraturan Bank Indonesia No. 19 Tahun 2017 Tentang Penyelenggaraan Teknologi Finansial, Lembaran Negara Republik Indonesia (LNRI) Tahun 2017 Nomor 245, dan Tambahan Lembaran Negara (TLN) Nomor 6142, Pasal 1 angka (1).

${ }^{6}$ Muliaman D. Hadad, "Financial Technology (Fintech) di Indonesia)", (makalah disampaikan pada Kuliah Umum Tentang Fintech, Jakarta, 2 Juni 2017), hal. 2.
} 
1. Fintech Weekly : Fintech is a line of business based on using software to provide financial servise. Financial technology companies are generally startups founded with the purpose of disrupting incumbent financial system and corporations that rely less on software.

2. Arner et al (2015): Fintech refers to the use of technology to deliver fiancial solutions.

3. PWC : Fintech is a dynamic segment intersection of the financial services and technology sectors where technology-focused start ups and new market entrants innovate the products and services currently provided by the traditional financial services industry.

4. Value-Stream: Fintech is the technology that serves the clients of financial institution, covering not only the back and middle offices but also the coveted front office that far so long has been humandriven.

5. Kantox FX: Fintech is a contraction of finance and technology refers to companies that provide financial services through the engagement of technology.

6. Fintech is technologies that can be used in the financial sector to help traditional companies innovate ${ }^{7}$.

Dari berbagai definisi mengenai Fintech tersebut di atas, dapat disimpulkan pada intinya Fintech adalah hasil kolaborasi antara teknologi informasi dengan bidang keuangan yang melahirkan produk, layanan dan model bisnis baru yang pada gilirannya dapat dimanfaatkan oleh masyarakat untuk mempermudah kegiatannya di bidang keuangan. Fintech muncul sebagai Inovasi Disruptif yang berhasil mentransformasikan suatu sistem atau pasar yang eksisting dengan memperkenalkan kepraktisan, kemudahan akses, kenyamanan dan biaya yang ekonomis. Di Indonesia terdapat 5 (lima) kategori Fintech, yaitu ${ }^{8}$ :

a. Sistem Pembayaran, mencakup otorisasi, kliring, penyelesaian akhir, dan pelaksanaan pembayaran, contohnya antara lain penggunaan teknologi blockechain atau distributed ledger untuk penyelenggaraan transfer dana, uang elektronik, dompet elektronik, dan mobile payments.

b. Pendukung Pasar, merupakan Fintech yang menggunakan teknologi informasi dan/atau teknologi elektronik untuk memfasilitasi pemberian informasi yang lebih cepat dan lebih murah terkait dengan produk dan/atau layanan jasa keuangan kepada masyarakat, contohnya antara lain penyediaan data perbandingan informasi produk atau layanan jasa keuangan.

${ }^{7}$ Fan Minmin and Yang Wang, "Figuring The Future Of Financial Technology", China Daily European Edition, (2 December 2016).

${ }^{8}$ Indonesia, Peraturan Bank Indonesia No. 19 Tahun 2017 Tentang Penyelenggaraan Teknologi Finansial, Lembaran Negara Republik Indonesia (LNRI) Tahun 2017 Nomor 245, dan Tambahan Lembaran Negara (TLN) Nomor 6142, Pasal 3 ayat (1). 
c. Manajemen Investasi Dan Manajemen Risiko, contohnya antara lain penyediaan produk investasi online dan asuransi online.

d. Pinjaman, Pembiayaan, Dan Penyediaan Modal, contohnya antara lain layanan pinjam meminjam uang berbasis teknologi informasi (peer-to-peer lending) serta pembiayaan atau penggalangan dana berbasis teknologi informasi (crowd-funding).

e. Jasa Finansial Lainnya.

Di masa depan, Fintech akan memberikan pengaruh yang besar di bidang layanan keuangan digital dengan melahirkan berbagai model bisnis baru yang mendatangkan banyak pilihan bagi masyarakat. With the development of information, communications and technology (ICT), the fintech industry will expand in the future. It will not only appear in new niche markets, such as peer-to-peer (P2P) lending but will also have great influence on traditional financial markets. In the future, the development of fintech will have different characteristics due to three main elements: the financial environment, technology and innovation?. Dalam penelitian ini, bidang Fintech yang dibahas hanya terkait layanan pinjam meminjam uang berbasis teknologi informasi, untuk selanjutnya dalam penelitian ini akan menggunakan istilah P2P Lending.

P2P Lending adalah penyelenggaraan layanan jasa keuangan untuk mempertemukan Pemberi Pinjaman dengan Penerima Pinjaman dalam rangka melakukan perjanjian pinjam meminjam dalam mata uang rupiah secara langsung melalui sistem elektronik dengan menggunakan jaringan internet ${ }^{10}$. P2P Lending menghadirkan layanan dan model bisnis baru di bidang keuangan berupa aplikasi yang digunakan sebagai sarana untuk mempertemukan Pemberi Pinjaman dengan Penerima Pinjaman, dengan menggunakan jaringan internet. Kehadiran P2P Lending tidak bisa dilepaskan dari kebutuhan masyarakat untuk memperoleh pinjaman uang, yang bisa saja diperoleh melalui bank, namun persyaratnya banyak dan pencairan pinjamannya cukup memakan waktu. Meski baru di tahap awal, Fintech mempunyai efek menghancurkan "rumah bank" yang kita kenal, mungkin ada yang pernah mendengar ucapan Bill Gates, "Banking is necessary, banks are not'? Ya, kini bank bukan lagi satu-satunya sumber utama pembiayaan ${ }^{11}$. Adanya pilihan memperoleh pinjaman yang mudah dan praktis itulah yang membuat masyarakat memanfaatkan P2P Lending untuk memenuhi kebutuhan keuangan jangka pendek. P2P

${ }^{9}$ Fan Minmin and Yang Wang, "Figuring The Future Of Financial Technology", China Daily European Edition, (2 December 2016), hal. 11.

${ }^{10}$ Indonesia, Peraturan Otoritas Jasa Keuangan No. 77 Tahun 2016 Tentang Layanan Pinjam Meminjam Uang Berbasis Teknologi Informasi, Lembaran Negara Republik Indonesia (LNRI) Tahun 2016 Nomor 324, dan Tambahan Lembaran Negara (TLN) Nomor 6005, Pasal 1 Angka (3).

${ }^{11}$ Rhenald Kasali, Disruption, cet. 6, (Jakarta : PT Gramedia Pustaka Utama, 2017), hal. 97. 
Lending sangat membantu dalam meningkatkan akses masyarakat terhadap produk jasa keuangan secara online dengan berbagai pihak tanpa perlu saling mengenal ${ }^{12}$.

Terdapat tiga pihak dalam P2P Lending, (i) Penyelenggara, yaitu badan hukum Indonesia yang menyediakan, mengelola, dan mengoperasikan layanan pinjam meminjam uang berbasis teknologi informasi ${ }^{13}$ (Penyelenggara P2P Lending),

(ii) Penerima Pinjaman, yaitu orang dan/atau badan hukum yang mempunyai utang karena perjanjian layanan pinjam meminjam uang berbasis teknologi informas ${ }^{14}$, dan (iii) Pemberi Pinjaman, yaitu orang, badan hukum, dan/atau badan usaha yang mempunyai piutang karena perjanjian layanan pinjam meminjam uang berbasis teknologi informasi ${ }^{15}$. Penerima Pinjaman dan Pemberi Pinjaman merupakan Pengguna layanan P2P Lending ${ }^{16}$. Konsep dasar dari P2P adalah tidak adanya pihak perantara, sehingga pengguna layanan mendapatkan manfaat berupa kecepatan dan efisiensi karena dapat berurusan langsung dengan pihak terkait (Pemberi Pinjaman dapat langsung memberikan pinjamannya kepada Penerima Pinjaman). Menurut pendapat Dana Moore dan John Kebeler, keduanya ahli di bidang P2P software start up mengatakan bahwa " in P2P, there is no middleman, so users benefit from the speed an efficiency of dealing directly with the desired participant" ${ }^{17}$. Perlindungan data pribadi merupakan hak konstitusional Warga Negara Indonesia sebagaimana diatur dalam UUD 1945 Amandemen II, pada intinya setiap orang berhak atas perlindungan diri pribadi, keluarga, kehormatan, martabat, dan harta benda yang di bawah kekuasaannya, serta berhak atas rasa aman dan perlindungan dari ancaman ketakutan untuk berbuat atau tidak berbuat sesuatu yang merupakan hak asasi ${ }^{18}$. Pemanfaatan P2P Lending oleh Penerima Pinjaman tidak saja untuk memenuhi kebutuhan keuangannya, namun juga menimbulkan tantangan terkait perlindungan data pribadinya. Salah satu perlindungan privasi dan data pribadi tersebut berkenaan bagaimana data pribadi tersebut akan diproses, termasuk data sensitif dari pengguna yang apabila disebarkan ke pihak yang tidak bertanggung jawab akan berpotensi menimbulkan kerugian finansial, bahkan mengancam keamanan dan keselamatan pemiliknya ${ }^{19}$. Dalam P2P Lending, terdapat data Pemberi

\footnotetext{
${ }^{12}$ Indonesia, Peraturan Otoritas Jasa Keuangan No. 77 Tahun 2016 Tentang Layanan Pinjam Meminjam Uang Berbasis Teknologi Informasi, Lembaran Negara Republik Indonesia (LNRI) Tahun 2016 Nomor 324, dan Tambahan Lembaran Negara (TLN) Nomor 6005, Penjelasan.

${ }^{13}$ Ibid, Pasal 1 Angka (6).

${ }^{14}$ Ibid, Pasal 1 Angka (7).

${ }^{15}$ Ibid, Pasal 1 Angka (8).

${ }^{16}$ Ibid, Pasal 1 Angka (9).

${ }^{17}$ Dana Moore and John Hebeler, Peer to Peer : Building Secure, Scalable and Manageable Networks, (California : The McGraw-Hill Companies, 2002), hal. 5.

${ }^{18}$ Indonesia, Undang-Undang Dasar 1945 Amandemen II, Pasal 28 Huruf (G) Ayat (1).

${ }^{21}$ Sinta Dewi Rosadi, Perlindungan Privasi Dan Data Pribadi Dalam Era Ekonomi Digital Di Indonesia, “Jurnal Veritas et Justicia”, Vol. 4, No. 1, 2018, 88-110, hal 88.
} 
Pinjaman dan data Penerima Pinjaman, dalam penelitian ini yang akan dibahas hanya mengenai data Penerima Pinjaman, khususnya data pribadi. Hal ini menjadi isu hangat karena pernah terjadi penagihan pinjaman gagal oleh pihak ketiga menggunakan penyebarluasan data pribadi (berupa foto dan informasi pinjaman) Penerima Pinjaman, padahal data pribadi tersebut hanya boleh disimpan dan digunakan oleh Penyelenggara P2P Lending. Selain itu ada juga penggunaan data pribadi Penerima Pinjaman berupa data KTP dipakai untuk meminjam di aplikasi lain tanpa seijin pemilik data pribadi tersebut. Proses perolehan, penggunaan, pemanfaatan, dan pengungkapan data pribadi Penerima Pinjaman dalam transaksi P2P Lending harus sesuai dengan peraturan perundangundangan yang berlaku. Data pribadi tersebut antara lain tidak boleh dibocorkan kepada pihak yang tidak berhak, tidak boleh digunakan untuk hal-hal di luar tujuan pengumpulan data pribadi dan harus dilindugi dengan baik serta harus jelas mekanisme pemusnahan data pribadi tersebut seperti apa. Penyelenggara P2P Lending harus melakukan langkahlangkah untuk melindungi data pirbadi Penerima Pinjaman yang disimpan dan diproses dalam sistem elektroniknya.

Perlindungan privasi dan data pribadi sebenarnya secara teori memiliki pengertian dan ruang lingkup yang berbeda karena privasi memiliki pengertian dan konteks yang lebih abstrak dan luas, yaitu hak untuk tidak diganggu (non-interference), akses terbatas (limited accessibility) atau kendali atas informasi pribadi (information control), sedangkan perlindungan data pribadi adalah perlindungan secara khsusus tentang bagaimana undang-undang melindungi, bagaimana data pribadi dikumpulkan, didaftarkan, disimpan dan dieksploitasi dan disebarluaskan ${ }^{20}$. Dalam praktik, kedua istilah ini seringkali dipersepsikan sama sehingga pada tahun 2010-an, beberapa ahli hukum privasi internasional mencoba menggabungkan dua pengertian ini menjadi data privasi ${ }^{21}$. Dalam penelitian ini akan menggunakan istilah data pribadi, menyesuaikan dengan peraturan perundang-undangan yang mengatur P2P Lending.

Berdasarkan hal-hal tersebut di atas, berikut ini rumusan permasalahan yang akan dibahas dalam penelitian ini, yaitu :

1. Bagaimana perlindungan terhadap data pribadi Penerima Pinjaman dalam P2P Lending di Indonesia?

${ }^{20}$ Lee A. Bygrave, Data Privacy Law An International Perspective, (Oxford : Oxford University Press, 2014), hlm. 1 dalam Sinta Dewi Rosadi, Cyber Law : Aspek Data Privasi Menurut Hukum Internasional, Regional dan Nasional, cet.1, (Bandung : PT Refika Aditama, 2015), hal. 1.

${ }^{21}$ Rosadi, Cyber Law : Aspek Data Privasi Menurut Hukum Internasional, Regional dan Nasional, hal. 2 . 
2. Bagaimana penerapan Prinsip Itikad Baik dalam penagihan pinjaman gagal bayar P2P Lending di Indonesia yang memanfaatkan data pribadi Penerima Pinjaman?

\section{METODE PENELITIAN}

Metode penelitian yang digunakan dalam penelitian ini adalah penelitian hukum normatif atau penelitian hukum doktrinal, yaitu penelitian perpusatakaan atau studi dokumen karena penelitian ini dilakukan atau ditujukan hanya pada peraturan-peraturan yang tertulis atau bahan-bahan hukum yang $\operatorname{lain}^{22}$. Penelitian doktrinal terdiri dari penelitian yang berupa usaha inventarisasi hukum positif, penemuan asas-asas dan falsafah (dogma atau doktrin) hukum positif ${ }^{23}$. Penelitian ini bersifat deskriptif, dimaksudkan untuk memberikan data yang seteliti mungkin tentang manusia, keadaan atau gejala-gejala lainnya dalam memperkuat teori-teori lama ${ }^{24}$. Dalam penelitian ini yang akan digunakan adalah Teori Perlindungan Data Privasi, yang pertama kali dikembangkan oleh Warren dan Brandeis yang menulis sebuah artikel di dalam Jurnal Ilmiah, Fakultas Hukus, Universitas Harvard yang berjudul "The Right to Privacy" 25 . Mereka menyatakan bahwa : "Privasi is the right to enjoy life and the right to be left alone and this development of the law was inevitable and demanded of legal recognition", privasi adalah hak untuk menikmati hidup dan menuntut hukum untuk melindungi privasi.

Jenis dan data yang digunakan dalam penelitian ini adalah bahan hukum primer dan bahan hukum sekunder. Bahan hukum primer merupakan bahan hukum yang bersifat autoritatif, artinya mempunyai otoritas ${ }^{26}$. Bahan-bahan hukum primer terdiri dari perundang-undangan, catatan-catatan resmi atau risalah dalam pembuatan perundangundangan dan putusan-putusan hakim ${ }^{27}$. Adapun bahan-bahan sekunder berupa semua publikasi tentang hukum, meliputi buku-buku teks, kamus-kamus hukum, jurnal-jurnal hukum dan komentar-komentar atas putusan pengadilan. Setelah penulis mengumpulkan sumber bahan hukum, dalam penelitian ini penulis menggunakan pendekatan undangundang (statute approach), yaitu dilakukan dengan menelaah semua undang-undang dan

\footnotetext{
${ }^{22}$ Soerjono Soekanto dan Sri Mamudji, Penelitian Hukum Normatif, cet ke-8 (Jakarta : PT Raja Grafindo Persada, 2004), hal. 4.

${ }^{23}$ E.Saefullah Wiradipradja, Penuntun Praktis Metode Penelitian dan Penelitian Karya Ilmiah, cet. 2 , (Bandung : CV Keni Media, 2016), hal. 28.

${ }^{24}$ Soerjono Soekanto, Pengantar Penelitian Hukum, (Jakarta : UI Press, 2015), hal. 10.

${ }^{25}$ Hofstadler dan Horowitz, The Right of Privacy, (New York : Central Book Company, 1964), hlm. 1011 dalam Rosadi, Cyber Law : Aspek Data Privasi Menurut Hukum Internasional, Regional dan Nasional, hal. 23 .

${ }^{26}$ Peter Mahmud Marzuki, Penelitian Hukum, (Jakarta : Prenadamedia Group, 2014), hal. 181.

${ }^{27}$ Ibid.
} 
regulasi yang bersangkut paut dengan isu hukum yang sedang ditangani ${ }^{28}$. Penelitian ini adalah penelitian hukum normatif, sehingga metodenya analisa datanya bersifat kualitatif, tidak berbentuk angka ${ }^{29}$.

\section{PEMBAHASAN}

\section{A. Perlindungan Terhadap Data Pribadi Penerima Pinjaman Dalam P2P Lending di Indonesia}

Tantangan terbesar dari seorang manusia yang ditimbulkan oleh teknologi informasi terkini adalah aspek privasi (privacy) $)^{30}$. Manusia secara naluriah memahami mengapa aspek privasi (privacy) menjadi sangat penting, namun kenyataannya hari ini penulusuran, penumpulan, penelisikan dan analisis perilaku dari berbagai informasi tentang manusia adalah bagian terpenting dari konektivitas baru peradaban Big Data ${ }^{31}$. Semakin banyak bisnis yang sadar akan pentingnya Big Data sebagai sumber strategi, dimana dengan menganalisa history pembelian konsumen, sebuah bisnis dapat dengan mudah mengidentifikasi tren dan pola kebutuhan konsumen. More and more businesses are waking up to the importance of Big Data as a strategic resource ${ }^{32}$. Perdebatan tentang permasalahanpermasalahan mendasar seperti dampak pada kehidupan batin manusia dari hilangnya kendali atas data pribadi terus akan meningkat di tahun-tahun mendatang ${ }^{33}$. Permasalahan mengenai perlindungan data pribadi Penerima Pinjaman muncul dalam P2P Lending yang kegiatannya menggunakan teknologi informasi. Dejan Z. Jankovic berpendapat bahwa sekali data perbadi masuk kepada sistem teknologi informasi, maka data pribadi sudah tidak dapat lagi dikontrol dengan ketat oleh pemiliknya.

Nowadays, processing of personal data is mostly performed automatically in IT systems. Once entered into any IT system such as government's or corporate database, personal information is not any more in strict control of its owner. Therefore there is serious concern of people regarding the adequate use oftheir personal information ${ }^{34}$.

\footnotetext{
${ }^{28}$ Ibid.

${ }^{29}$ E.Saefullah Wiradipradja, Penuntun Praktis Metode Penelitian dan Penelitian Karya Ilmiah, hal. 28. ${ }^{30}$ Danrivanto Budhijanto, Cyber Law dan Revolusi Industri 4.0, cet. 1, (Bandung : Logoz Publishing, 2019), hal. 186.

${ }^{31}$ Ibid.

${ }^{32}$ Noriko Higashizawa and Yuri Aihara, Data Privacy Protection of Personal Information Versus Usage of Big Data: Introduction of the Recent Amendment to the Act on the Protection of Personal Information (Japan), "Defense Counsil Journal", Vol. 84, No. 4, 2017, 1-15, hal. 1.

${ }^{33}$ Ibid.

${ }^{34}$ Dejan Z. Jankovic, Key Security Measures For Personal Data Protection In IT Systems, "20"th Telecomunication Forum, TELFOR 2012”, 2012, 79-82, hal. 79.
} 
Penyelenggara P2P Lending sebagai Penyelenggara Sistem Elekteronik, dalam menjalankan kegiatan usahanya, mempunyai kewajiban terkait dengan data yang diperolehnya, yaitu ${ }^{35}$ :

a. Menjaga kerahasiaan, keutuhan, dan ketersediaan data pribadi, data transaksi, dan data keuangan yang dikelolanya sejak data diperoleh hingga data tersebut dimusnahkan;

b. Memastikan tersedianya proses autentikasi, verifikasi, dan validasi yang mendukung kenirsangkalan dalam mengakses, memproses, dan mengeksekusi data pribadi, data transaksi, dan data keuangan yang dikelolanya;

c. Menjamin bahwa perolehan, penggunaan, pemanfaatan, dan pengungkapan data pribadi, data transaksi, dan data keuangan yang diperoleh oleh Penyelenggara berdasarkan persetujuan pemilik data pribadi, data transaksi, dan data keuangan, kecuali ditentukan lain oleh ketentuan peraturan perundang-undangan;

d. Menyediakan media komunikasi lain selain Sistem Elektronik Layanan Pinjam Meminjam Uang Berbasis Teknologi Informasi untuk memastikan kelangsungan layanan nasabah yang dapat berupa surat elektronik, call center, atau media komunikasi lainnya; dan

e. Memberitahukan secara tertulis kepada pemilik data pribadi, data transaksi, dan data keuangan tersebut jika terjadi kegagalan dalam perlindungan kerahasiaan data pribadi, data transaksi, dan data keuangan yang dikelolanya.

Berdasarkan Peraturan Pemerintah No. 71 Tahun 2019 tentang Penyelenggaraan Sistem dan Transaksi Elektronik, Perlindungan Data Pribadi dilakukan dengan menerapkan prinsip-prinsip sebagai berikut:

1. Pengumpulan Data Pribadi dilakukan secara terbatas dan spesifik, sah secara hukum, adil, dengan sepengetahuan dan persetujuan dari pemilik Data Pribadi;

2. Pemrosesan Data Pribadi dilakukan sesuai dengan tujuannya dan menjamin hak pemilik Data Pribadi;

3. Pemrosesan Data Pribadi dilakukan secara akurat, lengkap, tidak menyesatkan, mutakhir, dapat dipertanggungjawabkan, dan memperhatikan tujuan pemrosesan;

4. Melindungi keamanan Data Pribadi dari kehilangan, penyalahgunaan, akses dan pengungkapan yang tidak sah, serta pengubahan atau perusakan Data Pribadi;

\footnotetext{
${ }^{35}$ Indonesia, Peraturan Otoritas Jasa Keuangan No. 77 Tahun 2016 Tentang Layanan Pinjam Meminjam Uang Berbasis Teknologi Informasi, Lembaran Negara Republik Indonesia (LNRI) Tahun 2016 Nomor 324, Tambahan Lembaran Negara (TLN) Nomor 6005, Pasal 26.
} 
5. Memberitahukan tujuan pengumpulan, aktivitas pemrosesan, dan kegagalan pelindungan Data Pribadi;

6. Pemusnahan/penghapusan Data Pribadi kecuali masih dalam masa retensi.

Dari kewajiban Penyelenggara P2P Lending tersebut terkait pemrosesan data, data Penerima Pinjaman yang wajib dilindungi (dijaga kerahasiaan dan keamanannya) meliputi tiga data, yaitu (i) data pribadi, (ii) data transaksi dan (iii) data keuangan. Sesuai dengan pendahuluan di atas, dalam penelitian ini, yang akan dibahas hanya khusus mengenai data pribadi Penerima Pinjaman. Di dalam POJK No. 77 Tahun 2016 tidak diatur mengenai data pribadi apa saja yang boleh diakses oleh Penyelenggara P2P Lending, oleh karenanya Penyelenggara P2P Lending dapat mengakses seluruh data pribadi Penerima Pinjaman yang tersimpan dalam storage smartphone Penerima Pinjaman. Akses tersebut diperoleh Penyelenggara P2P Lending saat calon penerima pinjaman mengajukan pinjaman melalui aplikasi P2P Lending, dimana calon penerima pinjaman harus memberikan "persetujuan" bahwa Penyelenggara P2P Lending dapat mengakses data, antara lain (i) daftar kontak nomor telepon, (ii) gambar dan/atau foto, (iii) lokasi, (iv) aplikasi apa saja yang di-download oleh calon penerima pinjaman dan lain sebagainya. Data pribadi ini digunakan oleh Penyelenggara, selain untuk melakukan analisa saat proses pemberian pinjaman, juga digunakan dalam penagihan pinjaman gagal bayar. Misalnya dengan memanfaatkan akses nomor telepon Penerima Pinjaman, Penyelenggara dapat dengan mudah memberikan info melalui Whatsaap dan/atau Short Message Service (SMS) kepada saudara-saudara dan/atau teman-teman Penerima Penerima bahwa yang bersangkutan belum membayar hutang, dengan tujuan Penerima Pinjaman merasa malu karena hutangnya disebarluaskan dan akhirnya membayar hutangnya tersebut.

Penerima Pinjaman yang tidak dapat atau belum dapat memenuhi kewajibannya membayar pinjamannya (dalam keadaan gagal bayar), maka dilakukan penagihan oleh Penyelenggara P2P Lending. Dalam penagihan tersebut, timbul permasalahn yang disebabkan Penyelenggara P2P Lending menggunakan data pribadi Penerima Pinjaman untuk memaksa, mengancam dan mengintimidasi Penerima Pinjaman agar membayar pinjaman yang telah jatuh tempo. Berbagai pelanggaran terkait penggunaan data pribadi Penerima Pinjaman dalam penagihan pinjaman gagal bayar, yaitu ${ }^{36}$ :

a. Pertama, pengambilan hampir seluruh informasi yang ada pada gawai peminjam sebanyak 1330 (seribu tiga ratus tiga puluh) orang korban.

${ }^{36}$ Lampiran I Surat OJK No. S-1091/NB.213/2018 tanggal 14 Desember 2018 perihal Perintah Penyelesaian Pengaduan Pengguna. 
b. Kedua, penagihan yang tidak hanya dilakukan kepada peminjam atau kontak darurat sebanyak 1100 (seribu seratus) orang korban.

c. Ketiga, penyebaran data pribadi sebanyak 915 (sembilan ratus lima belas) orang korban.

d. Keempat, penyebaran foto dan informasi pinjaman ke kontak yang ada di gawai peminjam sebanyak 903 (sembilan ratus tiga) orang korban.

e. Kelima, data KTP dipakai untuk meminjam di aplikasi lain yang oleh penyelenggara aplikasi pinjaman online tanpa seizin peminjam sebanyak 1 (satu) orang korban.

Salah satu contoh penyebaran data pribadi Penerima Pinjaman ${ }^{37}$, yaitu Penyelenggara P2P Lending melalui perusahaan alih daya jasa penagihan membuat Whatsapp Group dengan judul "Hutang Sdr. XXX", beranggotakan teman-teman dekat dan/atau saudara-saudara Penerima Pinjaman, kemudian dalam Whatsapp Group tersebut disebarkan foto-foto Penerima Pinjaman disertai kata-kata, antara lain; (i) "Orang ini banyak dicari kolektor karena utang dia dengan perusahaan ada dimana-mana. Hati-hati bagi yang mengenal orang tersebue', (ii) "Selamat siang Bapak/Ibu. Saya dari agency YYY penagihan. Bagi Bapak/Ibu yang mengenal Sdr. XXX, tolong sampaikan peihal utangnya segera dibayarkan hari ini. Maaf telah mengganggu. Terima Kasib" atau "Saya simpang semuna kontak HPO Anda. Jika hari ini gak ada pembayaran saya akan menyebar semua kontak HP Anda". Pembuatan Whatsapp Group seperti ini sebagai sarana untuk menyebarkan data pribadi Penerima Pinjaman dengan tujuan agar Penerima Pinjaman merasa malu mempunyai hutang yang belum dibayar dapat terjadi karena Penyelenggara P2P Lending telah menyimpan foto wajah Penerima Pinjaman dan mengakses data pribadi berupa daftar kontak Penerima Pinjaman. Data pribadi tersebut kemudian diolah sedemikian rupa melalui kecerdasan buatan atau Artificial Intelligence yang dimiliki Penyelenggara P2P Lending, sehingga dapat diketahui siapa saja orang-orang dekat yang sering berhubungan dengan Penerima Pinjaman. Artificial Intelligence tidak hanya digunakan untuk melakukan penagihan pinjaman gagal bayar, namun juga untuk menganalisa data pribadi Penerima Pinjaman apakah aman atau tidak untuk diberikan pinjaman.

Kemajuan yang mengesankan telah dibuat dalam Artificial Intelligence dalam beberapa tahun terakhir, didorong oleh peningkatan eksponensial dalam daya komputasi dan oleh ketersediaan data dalam jumlah besar, dari perangkat lunak yang digunakan untuk

${ }^{37}$ Ibid. 
menemukan obat baru untuk algoritma yang digunakan untuk memprediksi kepentingan budaya kita ${ }^{38}$. Pada dasarnya, teknologi informasi yang masuk dalam Revolusi Industri 4.0 sangat berhubungan dengan Artificial Intelligence. Hal ini sejalan dengan pendapat James Adams dan Richard Kletter yang menyatakan "What technologist call "the fourth industrial revolution" began in 2010 and is principally associated with the development of robotics, Artificial Intelligence, nanotechnology and the internet of things". Berdasarkan The New Oxford American Dictionary, $13^{\text {th }} \mathrm{ed}$. sebagaimana dikutip oleh James Barrat:

Artificial Intelligence (abbreviation: AI) noun is the theory and development of computer systems able to perform task that normally require human intelligence, such as visual perception, speech recognition, decision-making, and translation between languanges ${ }^{39}$.

Lebih lanjut James Barrat berpendapat :

On a supercomputer operating at a speed of 36.8 petaflops, or about twice the speed of a buman brain, an AI is improving its intelligence. It is rewriting its own program, specifically the part of its operating instruction that increase its aptitude in learning, problem solving, and decision making. At the same time, it devugs its code, finding and fixing errors, and measures its IQ against a catalogue of IQ test. Each rewrite takes just minutes. Its intelligence grows exponentially on a steep upward curve ${ }^{40}$.

Berdasarkan berbagai jenis pelanggaran dalam penagihan pinjaman gagal bayar tersebut, OJK kemudian mengeluarkan perintah pembatasan akses data pribadi calon penerima pinjaman atau Penerima Pinjaman pada smartphone yang inti isinya adalah perintah larangan kepada Penyelenggara P2P Lending dalam mengakses data pribadi pada smartphone calon penerima pinjaman, kecuali (i) lokasi, (ii) kamera dan (iii) mikropon ${ }^{41}$. Dengan adanya pembatasan akses data pribadi ini, Penyelenggara P2P Lending diminta untuk menghentikan akses data pribadi calon penerima pinjaman atau Penerima Pinjaman (di luar 3 data tersebut) paling lambat tanggal 14 Februari 2019. Dasar hukum dikeluarkannya pembatasan akses data pribadi tersebut adalah kewenangan OJK untuk melakukan pengawasan pengawasan, pemeriksaan, penyidikan, perlindungan Konsumen, dan tindakan lain terhadap Lembaga Jasa Keuangan, pelaku, dan/atau penunjang kegiatan jasa keuangan sebagaimana dimaksud dalam peraturan perundang-undangan di sektor jasa

\footnotetext{
${ }^{38}$ Danrivanto Budhijanto, Cyber Law dan Revolusi Industri 4.0, hal. 229.

${ }^{39}$ James Barrat, Artificial Intelligence And The End of The Human Era, (New York : Thomas Dunne Books, 2015), hal. 7

${ }^{40}$ Ibid.

${ }^{41}$ Surat Otoritas Jasa Keuangan No. S-72/NB.213/2019 tanggal 12 Februari 2019 perihal Perintah Pembatasan Akses Data Pribadi pada Smartphone Pengguna Fintech Lending.
} 
keuangan ${ }^{42}$. Asril Sitompul mengemukakan, di Jepang, salah satu hal yang diperhatikan sebagai penekanan pentingnya perlindungan atas privasi, yaitu informasi pribadi perlu dibatasi menurut tujuan penggunaanya dan harus diperoleh dari sumber yang sah, berisikan data yang akurat, dilindungi dengan baik dan secara transparan ${ }^{43}$.

Adanya 3 (tiga) data yang bisa diakses tersebut tentu telah dipertimbangkan bahwa hal tersebut yang paling sesuai dengan tujuan penggunaan data untuk kepentingan P2P Lending. Adapun rasionalitas mengapa 3 (tiga) data tersebut dapat diakses, yaitu (i) lokasi : untuk mengetahui lokasi calon penerima pinjaman atau Penerima Pinjaman. Selain itu, salah tujuan dikembangkan P2P Lending adalah untuk meningkatkan keuangan yang inklusif bagi seluruh kalangan masyarakat, sehingga dengan dapat diaksesnya lokasi, maka nanti dapat tersaji data calon penerima pinjaman atau Penerima Pinjaman berasal darimana saja, (ii) kamera : saat pengajuan pinjaman, calon Penerima Pinjaman wajib melakukan selfi full face dan close up bersama-sama dengan KTP yang bersangkutan, sehingga dengan dapat diaksesnya kamera, maka aplikasi P2P Lending dapat menyimpan data identitas Penerima Pinjaman, mikropon : ini dibutuhkan saat proses penagihan pinjaman dari pihak Penyelenggara P2P Lending melalui bagian penagihan (collection). Lokasi yang boleh diakses oleh Penyelenggara P2P Lending pada awalnya hanya berdasarkan GPS Location. Perkembangan selanjutnya atas permohonan dari Asosiasi Fintech Pendanaan Bersama Indonesia (AFPI) mengenai Permohonan Akses IMEI, akhirnya OJK mengeluarkan persetujuan bahwa lokasi yang boleh diakses adalah berdasarkan GPS Location dan GSM International Mobile Equipment Identity (IMEI) dalam rangka Electronic Know Your Customer (E-KYC) ${ }^{44}$.

Penyelenggara P2P Lending termasuk ke dalam Penyelenggara Sistem Elektronik karena Penyelenggara P2P Lending pada dasarnya mengoperasikan Sistem Elektronik dengan membuat suatu aplikasi pinjam meminjam uang berbasis teknologi informasi guna keperluan Penyelenggara itu sendiri dan untuk keperluan Pemberi Pinjaman maupun Penerima Pinjaman. Peraturan Menteri Komunikasi dan Informatika No. 20 Tahun 2016 tentang Perlindungan Data Pribadi Dalam Sistem Elektronik ("Permenkominfo No. 20 Tahun 2016”) mengatur bahwa yang dimaksud Penyelenggara Sistem Elektronik adalah

\footnotetext{
${ }^{42}$ Indonesia, Undang-Undang No. 21 Tahun 2011 Tentang Otoritas Jasa Keuangan, Lembaran Negara Republik Indonesia (LNRI) Nomor 111 Tahun 2011, dan Tambahan Lembaran Negara (TLN) Nomor 5253, Pasal 9 Huruf (c).

${ }^{43}$ Asril Sitompul, Hukum Internet : Pengenalan Mengenai Masalah Hukum di Cyberspace, cet. 2, (Bandung : PT Citra Aditya Bakti, 2004), hal. 27

${ }^{44}$ Surat Otoritas Jasa Keuangan No. S-327/NB.213/2019 tanggal 20 Juni 2019 perihal Persetujuan Pemberian Akses Data Pribadi berupa IMEI pada Smartphone Pengguna Fintech Lending.
} 
setiap orang, penyelenggara negara, badan usaha dan masyarakat yang menyediakan, mengelola, dan/atau mengoperasikan Sistem Elektronik secara sendiri-sendiri maupun bersama-sama kepada Pengguna Sistem Elektronik untuk keperluan dirinya dan/atau keperluan pihak lain ${ }^{45}$. Data pribadi adalah data perseorangan tertentu yang disimpan, dirawat dan dijaga kebenaran serta dilindungi kerahasiannya ${ }^{46}$. Terhadap data pribadi calon penerima pinjaman atau Penerima Pinjaman tersebut, Penyelenggara P2P Lending selaku Penyelenggara Sistem Elektronik mempunyai kewajiban ${ }^{47}$ :

a. menjaga kerahasiaan data pribadi yang diperoleh, dikumpulkan, diolah dan dianalisanya.

b. menggunakan data pribadi sesuai dengan kebutuhan Pengguna saja.

c. melindungi data pribadi beserta dokumen yang membuat data pribadi tersebut dari tindakan penyalahgunaan.

d. bertanggungjawab atas data pribadi yang terdapat dalam penguasaannya, baik penguasaan secara organisasi yang menjadi kewenangannya maupun perorangan, jika terjadi tindakan penyalahgunaan.

Berdasarkan Organisation for Economic Cooperation and Developtmen (OECD) Guidelines dan EU Directive on Personal Data sebagaimana dijelaskan oleh Sinta Dewi Rosadi, terdapat prinsip-prinsip perlindungan data privasi, yaitu ${ }^{48}$ :

1. Pembatasan Pengumpulan : harus ada batasan dalam pengumpulan data privasi. Data yang didapatkan harus menggunakan cara-cara yang sah secara hukum dan adil dan jika diperlukan dengan pengetahuan dan persetujuan dari orang yang bersangkutan.

2. Kualitas Data : data privasi harus sesuai dengan tujuan mengapa data itu digunakan dan harus akurat, lengkap serta sesuai dengan kekinian.

3. Spesifikasi Tujuan : tujuan mengapa data itu dikumpulkan harus spesifik dan setiap penggunaan selanjutnya dari tersebut harus terbatas hanya sesuai dengan spesifikasi tujuan tersebut.

\footnotetext{
${ }^{45}$ Indonesia, Peraturan Menteri Komunikasi dan Informatika No. 20 Tahun 2016 Tentang Perlindungan Data Pribadi Dalam Sistem Elektronik, Berita Negara Republik Indonesia (BNRI) Tahun 2016 Nomor 1829, Pasal 1 Angka (6).

${ }^{46}$ Ibid, Pasal 1 Angka (1).

${ }^{47}$ Ibid, Pasal 27.

${ }^{48}$ Rosadi, Cyber Law : Aspek Data Privasi Menurut Hukum Internasional, Regional dan Nasional, hal. 30-31.
} 
4. Penggunaan Pembatasan : data tidak boleh dibuka, tersedia untuk umum atau digunakan untuk tujuan di luar tujuan yang spesifik kecuali : (a) atas persetujuan pemilik data, atau (b) persetujuan otoritas hukum.

5. Langkah-langkah Pengamanan : data harus dilindungi dengan pengamanan yyang sesuai untuk melindunginya dari kehilangan, kerusakan, penggunaan, perubahan dan keterbukaan.

6. Keterbukaan : harus ada kebijakan umum mengenai keterbukaan terhadap data privasi.

7. Partisipasi Individu : individu harus memiliki hak untuk menghapus atau membenarnkan data mereka yang salah.

8. Pertanggungjawaban : pengatur data bertanggungjawab untuk mematuhi langkahlangkah ini.

Penyelenggara P2P Lending untuk dapat menjalankan kegiatan P2P Lending wajib memiliki Sertifikat Penyelenggara Sistem Elektronik (“Sertifikat PSE”) sebagaimana diatur dalam Pasal 8 ayat (3) huruf (e) POJK No. 77 Tahun 2016 ${ }^{49}$. Sertifikat PSE berlaku selama 5 (lima) tahun sebagai Tanda Terdaftar dalam Daftar Penyelenggara Sistem Elektronik $^{50}$. Bentuk perlindungan data pribadi yang wajib dilakukan oleh Penyelenggara Sistem Elektronik mencakup perlindungan terhadap perolehan, pengumpulan, pengolahan, penganalisaan, penyimpanan, penampilan, pengumuman, pengiriman, penyebarluasan dan pemusnahan data pribadi ${ }^{51}$. Perolehan dan pengumpulan data pribadi oleh Penyelenggara Sistem Elektronik harus dibatasi pada informasi yang relevan dan sesuai dengan tujuannya serta harus dilakukan secara akurat ${ }^{52}$. Kaitannya dengan data calon penerima pinjaman atau Penerima Pinjaman, maka perolehan dan pengumpulan data pribadi oleh Penyelenggara P2P Lending harus dibatasi pada informasi yang relevan dan sesuai dengan tujuannya, yaitu untuk analisa pemberian pinjaman. Dengan demikian sudah tepat dikeluarkan aturan pembatasan akses data pribadi calon penerima pinjaman

\footnotetext{
${ }^{49}$ Permohonan pendaftaran oleh Penyelenggara sebagaimana dimaksud pada ayat (1) dan ayat (2) disampaikan Direksi kepada Kepala Eksekutif Pengawas Perasuransian, Dana Pensiun, Lembaga Pembiayaan dan Lembaga Jasa Keuangan lainnya dengan menggunakan Formulir 1 sebagaimana tercantum dalam Lampiran yang merupakan bagian yang tidak terpisahkan dari peraturan OJK ini dan dilampiri dengan dokumen yang paling sedikit memuat : bukti kesiapan operasional kegiatan usaha berupa dokumen terkait Sistem Elektronik dan data kegiatan operasional.

${ }^{50}$ Indonesia, Peraturan Menteri Komunikasi dan Informatika No. 36 Tahun 2014 Tentang Tata Cara Pendaftaran Penyelenggara Sistem Elektronik, Berita Negara Republik Indonesia (BNRI) Tahun 2014 Nomor 1432, Pasal 10 Ayat (2) dan Pasal 11 Ayat (1).

${ }^{51}$ Indonesia, Peraturan Menteri Komunikasi dan Informatika No. 20 Tahun 2016 Tentang Perlindungan Data Pribadi Dalam Sistem Elektronik, Berita Negara Republik Indonesia (BNRI) Tahun 2016 Nomor 1829, Pasal 2 Ayat (1).

${ }^{52}$ Ibid, Pasal 7 Ayat (1).
} 
atau Penerima Pinjaman pada smartphone yang terbatas pada (i) lokasi, (ii) kamera dan (iii) mikropon. Pembatasan pengaksesan tersebut menurut penulis sesuai dengan prinsipprinsip yang diatur dalam OECD Guidelines dan EU Directive on Personal Data, terutama Prinsip Spesifikasi Tujuan dan Prinsip Pengggunaan Pembatasan.

Penerima Pinjaman yang sudah melunasi pinjamannya, dapat mengajukan lagi pinjaman kepada Penyelenggara P2P Lending yang sama atau mengajukan pinjaman kepada Penyelenggara P2P Lending yang berbeda. Dalam hal Penerima Pinjaman mengajukan pinjaman pada Penyelenggara P2P Lending yang berbeda, maka terhadap data pribadi Penerima Pinjaman yang telah disimpan oleh Penyelenggara P2P Lending yang lama dapat dilakukan dua pilihan. Pertama, dalam hal Penerima Pinjaman tidak meminta penghapusan data pribadi, maka Penyelenggara P2P Lending dapat menyimpan data pribadi tersebut dalam bentuk data terenkripsi selama 5 (lima) tahun, setelah itu dapat dihapus ${ }^{53}$. Perhitungan 5 (lima) tahun dimulai sejak Penerima Pinjaman terakhir menggunakan layanan dari Penyelenggara P2P Lending ${ }^{54}$. Kedua, Penerima Pinjaman meminta penghapusan data pribadi kepada Penyelenggara P2P Lending, sehingga Penyelenggara P2P Lending wajib menghapus data pribadi tersebut sesuai peraturan perundang-undangan yang berlaku ${ }^{55}$.

Berkaitan dengan perlindungan data pribadi Penerima Pinjaman, Penyelenggara P2P Lending juga harus melakukan sertifikasi Sistem Manajemen Pengamanan Informasi sebagaimana diatur dalam Peraturan Menteri Komunikasi dan Informatika No. 4 Tahun 2016 tentang Sistem Manajemen Pengamanan Informasi ("Permenkominfo No. 4 Tahun 2016”). Dalam Permenkominfo No. 4 Tahun 2016 diatur mengenai data pribadi56, yaitu data perseorangan tertentu yang disimpan, dirawat, dan dijaga kebenaran serta dilindungi kerahasiaannya (definisi ini sama dengan definisi data pribadi sebagaimana diatur dalam Permenkominfo No. 20 Tahun 2016). Penyelenggara P2P Lending sebagai Penyelenggara Sistem Elektronik harus menerapkan standar ISO/IEC 27001 dan ketentuan pengamanan yang ditetapkan oleh Instansi Pengawas dan Pengatur Sektornya ${ }^{57}$. ISO/IEC 27001 ini merupakan standar internasional yang disiapkan sebagai model untuk menetapkan, menerapkan, mengoperasikan, memantau, meninjau, memelihara dan meningkatkan

\footnotetext{
${ }^{53}$ Ibid, Pasal 15 Ayat (3) Huruf (b) dan Pasal 19.

${ }^{54}$ Ibid, Pasal 16.

${ }^{55}$ Ibid, Pasal 19.

${ }^{56}$ Indonesia, Peraturan Menteri Komunikasi dan Informatika No. 4 Tahun 2016 Tentang Sistem Manajemen Pengamanan Informasi, Berita Negara Republik Indonesia (BNRI) Tahun 2016 Nomor 551, Pasal 1 Angka (7).

${ }^{57}$ Ibid, Pasal 7.
} 
Sistem Manajemen Pengamanan Informasi. Penerapan standar ISO/IEC 27001 ini untuk memastikan perlindungan atas data pribadi Penerima Pinjaman demi tercapainya keamanan informasi, yaitu terjaganya kerahasiaan (confidentiality), keutuhan (integrity), dan ketersediaan (availability) informas ${ }^{58}$. Penulis menganalisa bahwa penerapan standar ISO/IEC 27001 merupakan bagian dari pelaksanakan Privacy by Design, yaitu suatu teori baru yang menitikberatkan pada pendekatan teknologi dan praktik bisnis untuk mengatur data privasi walaupun secara teknologi telah digunakan Privacy-Enhancing Teknologi (PETs) akan tetapi belum cukup untuk dapat melindungi data privasi ${ }^{59}$. Jadi perlindungan data privasi tidak cukup melalui regulasi tapi juga harus diikuti oleh sistem teknologi informasi, praktik bisnis pelaku usaha yang selalu melindungi dan memperhatikan hak-hak pengguna dan infratsruktur yang mendukung ${ }^{60}$. Agar Privacy by Design dapat diterapkan secara efektif, maka harus mengggunakan Prinsip Dasar, yaitu ${ }^{61}$ :

1. Proaktif, artinya harus dipersiapkan semua alat, sarana, infrastruktur, praktik bisnis untuk melindungi data privasi sebelum kerugian timbul.

2. Default Setting, artinya sistem dan infrastruktur harus secara otomatis dibuat untuk melindugi data privasi.

3. Design-embedded, artinya perlindungan data privasi disediakan dalam design IT da nada dalam kebijakan perusahaan dan praktik bisnis.

4. Transparansi, yaitu adanya keterbukaan informasi kepada semua pengguna tentang sistem dan praktik bisnis yang digunakan.

5. End to end security, Privacy by Design yang telah tertanam ke dalam sistem sebelum elemen pertama dari informasi yang dikumpulkan, menjangkau seluruh siklus hidup data yang terlibat, dari awal sampai akhir. Hal ini memastikan bahwa pada akhir proses, semua data secara aman hancur, secara tepat waktu.

6. Visibility and Transparancey-Keep it Open, Privacy by Design yang berusaha untuk meyakinkan semua pihak bahwa setiap praktik bisnis atau teknologi yang terlibat sesuai dengan janji-janji dan tujuan yang dinyatakan. Bagian komponen dan operasi tetap terlihat dan transparan.

\footnotetext{
${ }^{58}$ Ibid, Pasal 1 Angka (6).

${ }^{59}$ Rosadi, Cyber Law : Aspek Data Privasi Menurut Hukum Internasional, Regional dan Nasional, hal. 21.

${ }^{60}$ Ibid.

${ }^{61}$ http://www.privacybydesign.ca/index.php/about-pbd/landmark-resolution/ dalam Rosadi, Cyber Law : Aspek Data Privasi Menurut Hukum Internasional, Regional dan Nasional, hal. 21
} 
7. Respect User, yaitu menghargai pengguna dengan selalu memberikan informasi tentang kebijakan privasu dan kemudakan pengguna untuk dapat mengerti kebijakan privasi tersebut.

Aplikasi P2P Lending yang dasarnya adalah teknologi informasi yang memberikan komunikasi langsung antara orang yang satu dengan orang yang lain/P2P, dalam penerapannya selalu mengakses langsung informasi data pribadi orang yang memanfaatkan aplikasi tersebut dan semua hal yang berkaitan dengan teknologi informasi tidak dapat menjamin 100\% perlindungan data, akan selalu ada celah, sehingga dengan penerapan ISO/IEC 27001 diharapkan dapat meminimalisir hal tersebut. Many P2P application offer direct access to your information and services... the P2P applications could have security holes, or improper administrations could create one...P2P raises serius concerns, but nor activity or technology is 100 safe $e^{62}$.

Setiap Penyelenggara P2P Lending yang telah terdaftar di OJK, wajib memperoleh sertifikasi ISO/IEC 27001 agar dapat lolos dalam tahap perizinan, hal ini dinyatakan secara tegas saat OJK mengeluarkan Surat Tanda Terdaftar kepada setiap Penyelenggara P2P Lending dengan merujuk kepada ketentuan Pasal 28 ayat (2) Permenkominfo No. 4 Tahun 2016 bahwa "pada saat Peraturan Menteri ini mulai berlaku, Penyelenggara Sistem Elektronik. yang Sistem Elektroniknya baru beroperasi wajib dilakukan sertifikasi Sistem Manajemen Pengamanan Informasi paling lambat 1 (satu) tabun sejak beroperasinya Sistem Elektronik." .

\section{B. Penerapan Prinsip Itikad Baik Dalam Penagihan Pinjaman Gagal Bayar P2P Lending di Indonesia Yang Menggunakan Data Pribadi Penerima Pinjaman}

Penagihan pinjaman gagal bayar dengan memanfaatkan data pribadi Penerima Pinjaman dapat dilakukan sendiri oleh Penyelenggara P2P Lending, maupun oleh pihak ketiga yang telah ditunjuk oleh Penyelenggara P2P Lending tersebut. Persoalan mengenai perlindungan data pribadi Penerima Pinjaman muncul ketika Penyelenggara P2P Lending menggunakan jasa pihak ketiga untuk melakukan penagihan, hal ini disebabkan Penyelenggara P2P Lending tersebut memberikan data pribadi Penerima Pinjaman kepada pihak ketiga, minimalnya berupa data KTP dan nomor HP yang bersangkutan. Pemberian data pribadi dari Penyelenggara P2P Lending kepada pihak ketiga harus mendapat persetujuan dari Penerima Pinjaman selaku pemilik data pribadi tersebut ${ }^{63}$, hal ini oleh

\footnotetext{
${ }^{62}$ Dana Moore and John Hebeler, Peer to Peer : Building Secure, Scalable and Manageable Networks, hlm. 27.

${ }^{63}$ Indonesia, Peraturan Menteri Komunikasi dan Informatika No. 20 Tahun 2016 Tentang Perlindungan Data Pribadi Dalam Sistem Elektronik, Berita Negara Republik Indonesia (BNRI) Tahun 2016 Nomor 1829, Pasal 24 Ayat (1).
} 
karena kegiatan tersebut termasuk ke dalam kegiatan menyebarluaskan data pribadi. Penyelenggara P2P Lending yang dalam penagihannya menggunakan jasa pihak ketiga, maka di dalam Perjanjian Pinjam Meminjam Uang antara Pemberi Pinjaman dengan Penerima Pinjaman wajib mencantumkan dengan jelas bahwa penagihan pinjaman gagal bayar hanya akan dilakukan oleh pihak $\mathrm{X}$ selaku pihak ketiga yang ditunjuk oleh Penyelenggara P2P Lending. Pencantuman klausul ini untuk menghindari agar jangan sampai terjadi pihak X tersebut melakukan "subkon" lagi proses penagihannya kepada pihak lainnya, jika hal ini terjadi, maka data pribadi Penerima Pinjaman akan sulit dilindungi dan kemungkinan besar dapat disalahgunakan.

Dalam penagihan pinjaman gagal bayar, terdapat peraturan perundang-undangan yang perlu diperhatikan untuk melindungi kepentingan Penerima Pinjaman. Pertama, Kitab Undang-Undang Hukum Pidana (“KUHP”), antara lain yang harus diperhatikan adalah (i) larangan untuk menyerang kehormatan atau nama baik seseorang dengan menuduhkan sesuatu hal, yang maksudnya terang supaya hal itu diketahui umum ${ }^{64}$ (ancaman hukuman pidana penjara paling lama 9 bulan), dan (ii) larangan menyerang kehormatan atau nama baik seseorang dengan tulisan atau gambaran yang disiarkan, dipertunjukkan atau ditempelkan di muka umum ${ }^{65}$ (ancaman hukuman pidana penjara paling lama 1 tahun 4 bulan).

Kedua, Undang-Undang No. 19 Tahun 2016 tentang Perubahan atas UndangUndang No. 11 Tahun 2008 tentang Informasi Dan Transaksi Elektronik/UU ITE ("UU No. 19 Tahun 2016 tentang Perubahan UU ITE"), antara lain yang harus diperhatikan adalah (i) larangan mendistribusikan dan/atau mentransmisikan dan/atau membuat dapat diaksesnya Informasi Elektronik dan/atau Dokumen Elektronik yang memiliki muatan yang melanggar kesusilaan ${ }^{66}$ (ancaman hukuman pidana penjara paling lama 6 tahun), (ii) larangan mendistribusikan dan/atau mentransmisikan dan/atau membuat dapat diaksesnya Informasi Elektronik dan/atau Dokumen Elektronik yang memiliki muatan penghinaan dan/atau pencemaran nama baik ${ }^{67}$ (ancaman hukuman pidana penjara paling lama 4 tahun), (iii) larangan mendistribusikan dan/atau mentransmisikan dan/atau membuat dapat diaksesnya Informasi Elektronik dan/atau Dokumen Elektronik yang

\footnotetext{
${ }^{64}$ Kitab Undang-Undang Hukum Pidana, Pasal 310 Ayat (1).

${ }^{65}$ Kitab Undang-Undang Hukum Pidana, Pasal 310 Ayat (2).

${ }^{66}$ Indonesia, Undang-Undang No. 19 Tahun 2016 tentang Perubahan atas Undang-Undang Nomor 11

Tahun 2008 tentang Informasi Dan Transaksi Elektronik, Lembaran Negara Republik Indonesia (LNRI)

Nomor 251 Tahun 2016, dan Tambahan Lembaran Negara (TLN) Nomor 5952, Pasal 27 Ayat (1).

${ }^{67}$ Ibid, Pasal 27 Ayat (3).
} 
memiliki muatan pemerasan dan/atau pengancaman ${ }^{68}$ (ancaman hukuman pidana penjara paling lama 6 tahun), (iv) larangan menyebarkan berita bohong dan menyesatkan yang mengakibatkan kerugian konsumen dalam Transaksi Elektronik ${ }^{69}$ (ancaman hukuman pidana penjara paling lama 6 tahun), dan (v) larangan mengirimkan Informasi Elektronik dan/atau Dokumen Elektronik yang berisi ancaman kekerasan atau menakut-nakuti yang ditujukan secara pribadi ${ }^{70}$ (ancaman hukuman pidana penjara paling lama 4 tahun). Salah satu aspek penting yang diatur dalam UU ITE adalah aspek perlindungan privacy, penggunaan setiap informasi melalui media elektronik yang menyangkut data tentang pribadi seseorang harus dilakukan atas persetujuan dari orang yang bersangkutan, kecuali ditentukan lain oleh peraturan perundang-undangan ${ }^{71}$.

Ketiga, Peraturan Otoritas Jasa Keuangan No. 1/POJK.07/2013 tentang Perlindungan Konsumen Sektor Jasa Keuangan ("POJK No. 1 Tahun 2013”). Hal-hal yang harus diperhatikan adalah (i) Pelaku Usaha Jasa Keuangan (termasuk Penyelenggara P2P Lending) bertanggungjawab kepada Konsumen (Penerima Pinjaman secara hukum merupakan Konsumen) yang dilakukan oleh pihak ketiga ${ }^{72}$ yang bertindak untuk kepentingan Pelaku Usaha Jasa Keuangan ${ }^{73}$, dan (ii) Pelaku Usaha Jasa Keuangan dilarang dengan cara apapun memberikan data dan/atau informasi mengenai konsumennya kepada pihak ketiga, kecuali konsumen memberikan persetujuan tertulis dan/atau diwajibkan oleh peraturan perundang-undangan ${ }^{74}$. Pelanggaran terhadap POJK No. 1 Tahun 2013 dapat dikenakan sanksi administratif berupa (i) peringatan tertulis, (ii) denda yaitu kewajiban untuk membayar sejumlah uang tertentu, (iii) pembatasan kegiatan usaha, (iv) pembekuan kegiatan usaha; dan (v) pencabutan izin kegiatan usaha ${ }^{75}$. Penyelenggara P2P Lending perlu berhati-hati, meskipun sanksi yang dikenakan akibat pelanggaran terhadap POJK No. 1 Tahun 2013 hanya berupa sanksi administratif, namun OJK dapat mengumumkan sanksi administratif tersebut kepada masyarakat ${ }^{76}$, sehingga hal ini akan berpengaruh baik langsung maupun tidak langsung terhadap reputasi dari Penyelenggara

\footnotetext{
${ }^{68}$ Ibid, Pasal 27 Ayat (4).

${ }^{69}$ Ibid, Pasal 28 Ayat (1).

${ }^{70}$ Ibid, Pasal 29.

${ }^{71}$ Danrivanto Budhijanto, Hukum Telekomunikasi, Penyiaran dan Teknologi Informasi, cet. 2, (Bandung : PT Refika Aditama, 2013), hal.134 - 135.

${ }^{72}$ Dalam praktiknya, fungsi penagihan pinjaman ada yang dilakukan oleh perusahaan alih daya yang ditunjuk oleh Penyelenggara P2P Lending untuk melakukan penagihan.

${ }^{73}$ Indonesia, Peraturan Otoritas Jasa Keuangan Nomor 1 Tahun 2013 Tentang Perlindungan Konsumen Sektor Jasa Keuangan, Lembaran Negara Republik Indonesia (LNRI) Tahun 2013 Nomor 118, dan Tambahan Lembaran Negara (TLN) Nomor 5431, Pasal 30 Ayat (3).

${ }^{74}$ Ibid, Pasal 31 Ayat (1) dan Ayat (2).

${ }^{75}$ Ibid, Pasal 53 Ayat (1).

${ }^{76}$ Ibid, Pasal 53 Ayat (5).
} 
P2P Lending tersebut, yang pada gilirannya dapat berpengaruh kepada keputusan masyarakat untuk memakai atau tidak memakai aplikasi dari Penyelenggara P2P Lending yang telah diberi sanksi administratif tersebut.

$\underline{\text { Keempat, }}$ Code of Conduct Asosiasi Fintech Pendanaan Bersama Indonesia ("CoC AFPI"), yang mengatur 5 (lima) larangan penagihan:

a. Dilarang keras menghina, memprovokasi, menyindir, mengancam atau mengintimidasi debitur dan/atau pihak lainnya yang berkaitan dengan cara apap pun saat melakukan penagihan.

b. Dalam berkomunikasi, dilarang keras menghina, memancing, melecehkan, mengancam atau mengintimidasi debitur dan/atau pihak lainnya dengan cara apa pun.

c. Dilarang keras kapan saja, di mana saja, dengan cara apapun menyebarkan datadata pribadi dari debitur dan/atau pihak lainnya (termasuk foto-foto pelanggan, nomor kartu identitas, alamat, informasi kontak, seperti perjanjian pinjaman semua informasi dan lainnya). Menyebarkan informasi pribadi orang lain secara illegal, merupakan tindak kejahatan dan barang siapa yang melakukan akan diproses sesuai hukum yang berlaku.

d. Dilarang keras untuk menyarankan debitur dan/atau pihak ketiga untuk mengembalikan tunggakan/kewajiban ke akun lain, selain yang akun resmi yang telah ditetapkan selama proses pengumpulan/penagihan.

e. Dilarang keras untuk berpura-pura menjadi petugas resmi pemerintah, kejaksaan, pengadilan atau departemen pemerintah lainnya pada saat melakukan proses penagihan ke debitur dan/atau pihak ketiga lainnya.

Kelima, Pedoman Perilaku Pemberian Layanan Pinjam Meminjam Uang Berbasis Teknologi Informasi Secara Bertangggung Jawab ("Pedoman Perilaku AFPI”), mengatur prinsip itikad baik pada dasarnya bahwa dalam memfasilitasi kegiatan penawaran dan pemberian pinjaman sebagai platform atau marketplace, setiap Penyelenggara tetap wajib menerapkan prinsip itikad baik dengan memperhatikan kepentingan seluruh pihak yang terlibat, serta tanpa merendahkan harkat dan martabat anggota ${ }^{77}$. Selanjutnya dalam Bab III huruf C.3 mengatur bahwa Penyelenggara P2P Lending wajib menerapkan Prinsip Itikad Baik dalam penagihan pinjaman gagal bayar, baik penagihan itu dilakukan sendiri

\footnotetext{
${ }^{77}$ Pedoman Perilaku AFPI, Bab II Ketentuan Umum angka (6) huruf (c).
} 
oleh Penyelenggara P2P Lending, maupun penggunaan pihak ketiga dalam penagihan pinjaman gagal bayar, sebagai berikut :

\section{Penagihan Pinjaman Gagal Bayar oleh Penyelenggara P2P Lending :}

a. Setiap Penyelenggara wajib memiliki dan menyampaikan prosedur penyelesaian dan penagihan kepada Pemberi dan Penerima Pinjaman dalam terjadi gagal bayar pinjaman.

b. Setiap Penyelenggara wajib menyampaikan kepada Penerima Pinjaman dan Pemberi Pinjaman atas kegagalan pembayaran pinjaman antara lain :

1) Perihal pemberian surat peringatan.

2) Persyaratan penjadwalan atau restrykturisasi pinjaman.

3) Korespondensi dengan Penerima Pinjaman secara jarak jauh (desk collection), termasukk via telepon, email atau bentuk percakapan lainnya.

4) Perihal kunjungan atau komunikasi dengan tim penagihan;atau

5) Penghapusan pinjaman.

c. Seluruh karyawan internal penagihan dari perusahaan Penyelenggar diwajibkan untuk mendapatkan sertifikasi Agen Penagihan yang dikeluarkan oleh AFPI melalui mekanisme tes dan seleksi tertulis dan lisan yang ketat.

d. Setiap Penyelenggara tidak diperbolehkan melakukan penagihan secara langsung kepada Penerima Pinjaman gagal bayar setelah melewati batas keterlambatan lebih dari 90 (sembilan puluh) hari dihitung dari tanggal jatuh tempo pinjaman.

e. Penyelenggara wajib menginformasikan kepada peminjam secara detail mengenai resiko yang akan dihadapi oleh peminjam jika tidak menyelesaikan pinjaman mereka.

f. Prosedur penyelesaian dan penagihan sebagaimana tersebut di atas wajib memperhatikan kepentingan Pemberi Pinjmana dan Penerima Pinjaman.

g. Ketentuan lebih lanjut mengenai standar penagihan atas pinjaman gagal bayar akan diatur lebih lanjut di dalam pembaharuan berkala Pedoman Perilaku.

Penagihan Pinjaman Gagal Bayar oleh Pihak Ketiga :

a. Setiap Penyelenggara diperbolehkan menggunakan pihak ketiga perusahaan jasa pelaksanaan penagihan yang telah terdaftar di AFPI dan memiliki sertifikat untuk melakukan penagihan kepada peminjam yang juga dikeluarkan oleh AFPI melalui mekanisme audit Pedoman Pelaksanaan Penagihan dan juga audit finansial serta operasional perusahaan. Seluruh karyawan penagihan dari perusahaan jasa 
pelaksanaan penagihan juga diwajibkan untuk memperoleh sertifikasi Agen Penagihan yang dikeluarkan oleh AFPI.

b. Setiap Penyelenggara diiperbolehkan menggunakan pihak ketiga perusahaan jasa pelaksanaan penagihan yang telah diakui untuk tagihan yang telah melewati batas keterlambatan lebih dari 90 (Sembilan puluh) hari dihitung dari tanggal jatuh tempo pinjaman.

c. Setiap Penyelenggara dilarang menggunakan pihak ketiga perusahaan jasa pelaksanaan penagihan (baik orang perseorangan maupun korporasi) yang tergolong dakan daftar hitam otoritas dan/atau dari Asosiasi.

d. Daftar hitam sebagaimana dimaksud diatas akan disusun kemudian di dalam pembaruan berkala Pedoman Perilaku.

Prinsip itikad baik wajib diterapkan oleh Penyelenggara P2P Lending dalam setiap pengumpulan, penyimpanan dan penggunaan data pribadi Pengguna dan calon Pengguna ${ }^{78}$. Contoh kegiatan penggumpulan, penyimpanan dan pengunaan data pribadi konsumen yang dilakukan tanpa itikad baik, antara lain : (i) meminta data pribadi dari Pengguna meskipun belum ada layanan yang dapat diberikan kepada konsumen tersebut, (ii) mengumpulkan data pribadi yang tidak relevan dengan layanan yang akan diberikan kepada Pengguna, (iii) mengumpulkan data pribadi di luar data yang sudah disetujui untuk diberikan oleh Pengguna, (iv) menggunakan data pribadi untuk tujuan yang belum diberitahukan kepada Penggna, dan (v) mengumpulkan dan menyimpan data pribadi meskipun Penyelenggara belum memiliki sistem elektronik yang handal untuk melakukan kegiatan tersebut ${ }^{79}$.

Penerapan prinsip itikad baik ini wajib dilaksanakan oleh Penyelenggara P2P Lending oleh karena berdasarkan Pasal 3 UU ITE, pemanfaatan teknologi informasi dilaksanakan salah satunya berdasarkan prinsip itikad baik, yaitu para pihak dalam melakukan transaksi elektronik tidak bertujuan dengan secara sengaja dan tanpa hak atau melawan hukum mengakibatkan kerugian pihak lain tanpa sepengetahuan pihak lain tersebut ${ }^{80}$.

Pelanggaran terhadap Pedoman Perilaku AFPI dapat dikenakan sanksi berupa: (i) teguran tertulis, (ii) publikasi nama anggota dan ketentuan yang dilanggar kepada Otoritas Jasa Keuangan dan kepada masyarakat, (iii) pemberhentian sementara dari keanggotaan Asosiasi, (iv) pemberhentian tetap dari keanggotaan Asosiasi.

\footnotetext{
${ }^{78}$ Pedoman Perilaku AFPI, Bab III Pokok-Pokok Pengaturan, huruf C angka (2).

${ }^{79}$ Ibid.

${ }^{80}$ Danrivanto Budhijanto, Hukum Telekomunikasi, Penyiaran dan Teknologi Informasi, hal. 137
} 


\section{KESIMPULAN}

Perlindungan data pribadi Penerima Pinjaman dalam P2P Lending dilakukan dengan pembatasan akses data terhadap Penerima Pinjaman yang meliputi (i) lokasi, (ii) kamera dan (iii) mikropon, yang merupakan data paling sesuai dengan kepentingan P2P Lending. Data yang diperoleh oleh Penyelenggara P2P Lending wajib dijaga kerahasiaannya dan tidak boleh disalahhgunakan untuk kepentingan lainnya. Penyelenggara P2P Lending harus melakukan langkah-langkah perlindungan data pribadi Penerima Pinjaman, antara lain sesuai dengan Peraturan Menteri Komunikasi dan Informatika No. 20 Tahun 2016 Tentang Perlindungan Data Pribadi Dalam Sistem Elektronik dan Peraturan Menteri Komunikasi dan Informatika No. 4 Tahun 2016 tentang Sistem Manajemen Pengamanan Informasi, diantaranya menerapkan standar menerapkan standar ISO/IEC 27001. Penerapan standar ISO/IEC 27001 ini untuk memastikan perlindungan atas data pribadi Penerima Pinjaman demi tercapainya keamanan informasi, yaitu terjaganya kerahasiaan (confidentiality), keutuhan (integrity), dan ketersediaan (availability) informasi. Selain itu, Penyelenggara P2P Lending harus melaksanakan prinsip perlindungan data pribadi sebagaimana Peraturan Pemerintah No. 71 Tahun 2019 tentang Penyelenggaraan Sistem dan Transaksi Elektronik.

Penagihan pinjaman gagal bayar yang memanfaatkan data pribadi Penerima Pinjaman harus dilaksanakan dengan Prinsip Itikad Baik, terutama dalam hal Penyelenggara P2P Lending menggunakan jasa penagihan pihak ketiga, dimana terdapat penyebarluasan data pribadi dari Penyelenggara P2P Lending kepada pihak ketiga. Bentuk itikad baik ini dari Penyelenggara P2P Lending, yaitu :

a. Setiap penggunaan dan/atau penyerbaluasan data pribadi dalam penagihan pinjaman gagal bayar wajib memperhatikan ketentuan KUHP, Undang-Undang No. 19 Tahun 2016 tentang Perubahan atas Undang-Undang No. 11 Tahun 2008 tentang Informasi Dan Transaksi Elektronik, Peraturan Otoritas Jasa Keuangan No. 1/POJK.07/2013 tentang Perlindungan Konsumen Sektor Jasa Keuangan, Code of Conduct AFPI dan Pedoman Perilaku AFPI. Penggunaan dan/atau penyebarluasan data pribadi berupa foto berikut KTP calon Penerima Pinjaman dan/atau Penerima Pinjaman tidak boleh disalahgunakan untuk kepentingan lainnya dan tanpa persetujuan Penerima Pinjaman.

b. Penggunaan jasa penagihan pinjaman gagal bayar hanya boleh menggunakan jasa pihak ketiga yang telah terdaftar di AFPI dan memiliki sertifikat untuk melakukan 
penagihan kepada Penerima Pinjaman. Penyebarluasan data pribadi Penerima Pinjaman dari Penyelenggara P2P Lending kepada pihak ketiga tersebut wajib atas persetujuan dari Penerima Pinjaman.

Dilarang keras menghina, memprovokasi, menyindir, mengancam atau mengintimidasi Penerima Pinjaman saat penagihan pinjaman gagal bayar dengan menggunakan data pribadi Penerima Pinjaman berupa foto Penerima Pinjaman yang disebarluaskan melalui whatsapp, contohnya "Orang ini banyak dicari kolektor karena utang dia dengan perusahaan ada dimana-mana. Hati-hati bagi yang mengenal orang tersebut'.

\section{SARAN}

Pemerintah Indonesia bersama dengan DPR perlu merumuskan Undang-Undang Perlindungan Data Pribadi yang secara khusus mengatur mengenai Perlindungan Data Pribadi karena peraturan perundang-undangan yang ada belum memberikan perlindungan yang maksimal. Hal ini mengingat perlu diatur mekanisme perlindungan data pribadi yang spesifik sebagai payung hukum perlindungan data pribadi dalam penggunaan teknologi informasi, dimana di dalamnya juga mengatur perlindungan data pribadi dalam kegiatan P2P Lending. Sebagai perbandingan, Singapura telah memiliki Undang-Undang Perlindungan Data Pribadi (Singapore's Personal Data Protection Act 2012).

AFPI selaku asosiasi yang beranggotakan Penyelenggara Fintech (termasuk di dalamnya Penyelenggara P2P Lending) harus memaksimalkan sarana pengaduan yang ada website www.afpi.or.id terkait adanya dugaan penyalahgunaan data pribadi Penerima Pinjaman dan/atau pengaduan tentang hal lainnya. AFPI perlu membuat Pedoman Teknis mengenai Tata Cara Penyelesaian Pengaduan yang didalamnya mengatur penyelesaian masalah penyalahgunaan data pribadi Penerima Pinjaman. Penyusunan Pedoman Teknis tersebut melibatkan Penyelenggara P2P Lending, OJK, Kementerian Kominfo dan Kepolisian, agar aspek hukum administrasi negara, perdata dan pidana dapat secara komprehensif diakomodir dalam pedoman teknis tersebut.

\section{DAFTAR PUSTAKA}

\section{Buku}

Adams, James and Kletter, Richard. Artificial Intelligence : Confronting The Revolution. Middletown : Endeavour Media Ltd., 2018. 
Barrat, James. Artificial Intelligence And The End of The Human Era. New York : Thomas Dunne Books, 2015.

Budhijanto, Danrivanto. Cyber Law dan Revolusi Industri 4.0. Cet. 1. Bandung : Logoz Publishing, 2019.

Budhijanto, Danrivanto. Hukum Telekomunikasi, Penyiaran dan Teknologi Informasi. Cet. 2. Bandung: PT Refika Aditama, 2013.

Kasali, Rhenald. Dismption. Cet. 6. Jakarta : PT Gramedia Pustaka Utama, 2017.

Makarim, Edmon. Tanggung Jawab Hukum Penyelenggara Sistem Elektronik. Jakarta: Raja Grafindo Persada, 2010.

Marzuki, Peter Mahmud. Penelitian Hukum. Jakarta : Prenadamedia Group, 2014.

Moore, Dana and Hebeler, John. Peer to Peer : Building Secure, Scalable and Manageable Networks. California : The McGraw-Hill Companies, 2002.

Rosadi, Sinta Dewi. Cyber Law : Aspek Data Privasi Menurut Hukum Internasional, Regional dan Nasional. Cet.1. Bandung : PT Refika Aditama, 2015.

Sanusi, Arsyad. Konvergensi Hukum dan Teknologi Informasi. Jakarta : Sasrawarna Printing, 2011.

Soekanto, Soerjono dan Mamudji, Sri. Penelitian Hukum Normatif. Cet ke-8. Jakarta : PT Raja Grafindo Persada, 2004.

Soekanto, Soerjono. Pengantar Penelitian Hukum. Jakarta : UI Press, 2015.

Sitompul, Asril. Hukum Internet : Pengenalan Mengenai Masalah Hukum di Cyberspace. Cet. 2. Bandung: PT Citra Aditya Bakti, 2004.

Wiradipradja, E.Saefullah. Penuntun Praktis Metode Penelitian dan Penelitian Karya Ilmiah. Cet. 2. Bandung : CV Keni Media, 2016.

\section{Jurnal}

Latumahina, Rosalinda Elsina. "Aspek Hukum Perlindungan Data Pribadi di Dunia Maya”. Jurnal Gema Aktualita, Vol. 3 No. 2, 2014, 14-25 : 14.

Rosadi, Sinta Dewi. "Perlindungan Privasi Dan Data Pribadi Dalam Era Ekonomi Digital Di Indonesia”. Jurnal Veritas et Justicia, Vol. 4, No. 1, 2018, 88-110 : 88.

Higashizawa, Noriko and Aihara, Yuri. "Data Privacy Protection of Personal Information Versus Usage of Big Data: Introduction of the Recent Amendment to the Act on the Protection of Personal Information (Japan)". Defense Counsil Journal, Vol. 84, No. 4, 2017, 1-15 : 1.

Jankovic, Dejan Z. “Key Security Measures For Personal Data Protection In IT Systems”. 20 th Telecomunication Forum, TELFOR 2012”, 2012, 79-82 : 79.

\section{Peraturan Perundang-Undangan}

Indonesia, Undang-Undang Dasar 1945 Amandemen II, Pasal 28 Huruf (G) Ayat (1).

Indonesia, Undang-Undang No. 21 Tahun 2011 Tentang Otoritas Jasa Keuangan, Lembaran Negara Republik Indonesia (LNRI) Nomor 111 Tahun 2011, dan Tambahan Lembaran Negara (TLN) Nomor 5253.

Indonesia, Undang-Undang No. 19 Tahun 2016 tentang Perubahan atas Undang-Undang 
Nomor 11 Tahun 2008 tentang Informasi Dan Transaksi Elektronik, Lembaran Negara Republik Indonesia (LNRI) Nomor 251 Tahun 2016, dan Tambahan Lembaran Negara (TLN) Nomor 5952.

Indonesia, Peraturan Otoritas Jasa Keuangan No. 77 Tahun 2016 Tentang Layanan Pinjam Meminjam Uang Berbasis Teknologi Informasi, Lembaran Negara Republik Indonesia (LNRI) Tahun 2016 Nomor 324, dan Tambahan Lembaran Negara (TLN) Nomor 600.

Indonesia, Peraturan Bank Indonesia No. 19 Tahun 2017 Tentang Penyelenggaraan Teknologi Finansial, Lembaran Negara Republik Indonesia (LNRI) Tahun 2017 Nomor 245, dan Tambahan Lembaran Negara (TLN) Nomor 6142.

Indonesia, Peraturan Menteri Komunikasi dan Informatika No. 20 Tahun 2016 Tentang Perlindungan Data Pribadi Dalam Sistem Elektronik, Berita Negara Republik Indonesia (BNRI) Tahun 2016 Nomor 1829.

Indonesia, Peraturan Menteri Komunikasi dan Informatika No. 36 Tahun 2014 Tentang Tata Cara Pendaftaran Penyelenggara Sistem Elektronik, Berita Negara Republik Indonesia (BNRI) Tahun 2014 Nomor 1432.

Indonesia, Peraturan Menteri Komunikasi dan Informatika No. 20 Tahun 2016 Tentang Perlindungan Data Pribadi Dalam Sistem Elektronik, Berita Negara Republik Indonesia (BNRI) Tahun 2016 Nomor 1829.

Indonesia, Peraturan Menteri Komunikasi dan Informatika No. 4 Tahun 2016 Tentang Sistem Manajemen Pengamanan Informasi.

Indonesia, Peraturan Otoritas Jasa Keuangan Nomor 1 Tahun 2013 Tentang Perlindungan Konsumen Sektor Jasa Keuangan, Lembaran Negara Republik Indonesia (LNRI) Tahun 2013 Nomor 118, dan Tambahan Lembaran Negara (TLN) Nomor 5431.

Indonesia, Peraturan Pemerintah No. 71 Tahun 2019 tentang Penyelenggaraan Sistem dan Transaksi Elektronik, Lembaran Negara Republik Indonesia (LNRI) Tahun 2019 Nomor 185, dan Tambahan Lembaran Negara (TLN) Nomor 6400.

Kitab Undang-Undang Hukum Pidana

\section{Bahan Seminar dan Lain-Lain}

Hadad, Muliaman D.. "Financial Technology (Fintech) di Indonesia)". Makalah disampaikan pada Kuliah Umum Tentang Fintech, Jakarta, 2 Juni 2017.

Minmin, Fan and Wang, Yang. "Figuring The Future Of Financial Technology" China Daily European Edition, (2 December 2016).

Lampiran I Surat OJK No. S-1091/NB.213/2018 tanggal 14 Desember 2018 perihal Perintah Penyelesaian Pengaduan Pengguna.

Surat Otoritas Jasa Keuangan No. S-72/NB.213/2019 tanggal 12 Februari 2019 perihal Perintah Pembatasan Akses Data Pribadi pada Smartphone Pengguna Fintech Lending.

Surat Otoritas Jasa Keuangan No. S-327/NB.213/2019 tanggal 20 Juni 2019 perihal Persetujuan Pemberian Akses Data Pribadi Berupa IMEI pada Smartphone Pengguna Fintech Lending. 
Pedoman Perilaku Pemberian Layanan Pinjam Meminjam Uang Berbasis Teknologi Informasi Secara Bertangggung Jawab ("Pedoman Perilaku AFPI").

Code of Conduct (CoC) AFPI. 